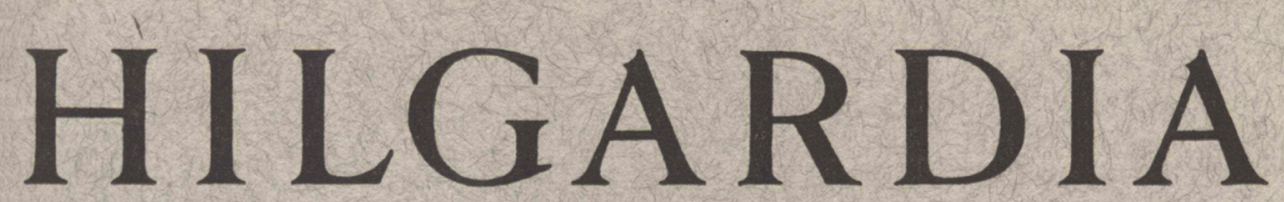

A Journal of Agricultural Science Published by the California Agricultural Experiment Station

\title{
TEMPERATURE RELATIONS OF POWDERY MILDEWS
}

C. E. YARWOOD, SOLIMAN SIDKY, MORRIS COHEN, and VINCENT SANTILLI 
The optimum temperature for powdery mildews (Erysiphaceae) as a group is about $21^{\circ} \mathrm{C}$, or 4 degrees lower than the average optimum for plant pathogens. Among the powdery mildews the optima for different species are about as follows: Erysiphe graminis, $17^{\circ} \mathrm{C} ;$ E. polygoni, $23^{\circ}$; E. cichoracearum, $22^{\circ}$; Sphaerotheca pannosa, $24^{\circ}$; Uncimula necator, $26^{\circ}$; and Podosphaera leucotricha, $16^{\circ}$. The five criteria of fungus activity used to assay the relation of temperature to powdery-mildew developmentnumber of conidia per conidiophore, rate of maturation of conidia, percentage germination of conidia, length of germ tubes in vitro, disease development, and length of hyphae in vivo-are considered to be of increasing merit in the order given.

Powdery-mildew conidia are shorter-lived than the spores of most fungi: they live only about $\mathbf{2}$ days in ordinary environments. At lower and higher temperatures they live for longer and shorter times, respectively. Attached spores in situ live longer than detached spores on glass. Fresh conidia on the host surface are more tolerant of high temperature than are the young colonies resulting from the growth of these conidia. 


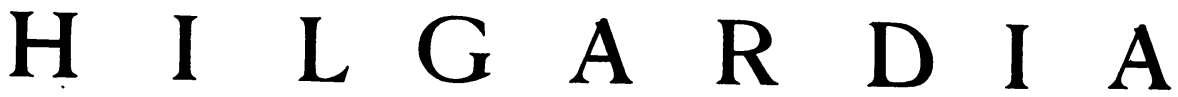

A Journal of Agricultural Science Published by

the California Agricultural Experiment Station

\begin{tabular}{lll}
\hline VoL. 22 & MARCH, 1954 & No. 17 \\
\hline
\end{tabular}

\section{TEMPERATURE RELATIONS OF POWDERY MILDEWS ${ }^{1}$}

\section{E. YARWOOD, SOLIMAN SIDKY, MORRIS COHEN, and VINCENT SANTILLI ${ }^{2}$}

The PRINCIPAL environmental factors affecting plant diseases are temperature, humidity, and light. It cannot safely be stated that temperature is more or less important than humidity or light; but it is certainly more easily and extensively studied. Temperature always acts in conjunction with some combination of humidity and light, and the nature of this combination may determine the response to temperature. This is especially true with powdery mildews and other fungi of foliage, where high temperatures are usually associated with high light intensity and low humidity in nature. Conventional temperature studies with plant diseases are conducted at a series of constant temperatures, with humidity and light fairly constant; whereas in nature there is usually a regular diurnal fluctuation in temperature, humidity, and light. This makes difficult the interpretation of results secured at constant temperatures or of events occurring under natural conditions.

The present report is a review of existing quantitative data on the temperature relations of powdery mildews (Erysiphaceae) and a presentation of some new data. Much of the published information is of nonquantitative nature, such as, "During warm humid weather, powdery mildew (Erysiphe cichoracearum) can cause severe injury," (Anonymous, 1950), or "The germination of the spores [of Uncinula necator, grape mildew] is favored by excessive cold on tender vegetative surfaces" (Taylor, 1923). This type of information will generally not be reviewed. Even some of the specific data, such as those of Bioletti (1907), are apparently based on records of field temperatures and may be of doubtful value.

Most data on temperature relations of plant-disease fungi are on the relation of temperature to the growth of the pathogen in an agar substrate (Togashi, 1949). This type of information is not available for any powdery mildew, since none has ever been cultured apart from its host. Therefore our knowledge of temperature relations for powdery mildews is less than for most important groups of fungi. However, many powdery-mildew conidia germinate on glass or agar surfaces, and some data on the relation of tem-

\footnotetext{
${ }^{1}$ Received for publication August 20, 1952.

${ }^{2} \mathrm{Mr}$. Yarwood is Professor of Plant Pathology and Plant Pathologist in the Experiment Station, Berkeley; Mr. Sidky is Plant Pathologist, Ministry of Agriculture, Cairo, Egypt; Mr. Cohen is Research Associate in Botany, Los Angeles; Mr. Santilli was a Graduate Assistant in Plant Pathology at the time of these studies.
} 
perature to percentage germination and germ-tube growth have been secured. By the use of detached leaves (Yarwood, 1946) extensive studies of the relation of temperature to powdery-mildew growth can be conducted in conventional small dark incubators.

\section{METHODS}

Powdery mildew of barley (Erysiphe graminis DC. on Hordeum vulgare L.), powdery mildew of bean ( $E$. polygoni DC. on Phaseolus vulgaris L.), powdery mildew of pea ( $E$. polygoni on Pisum sativum L.), powdery mildew of cantaloupe and cucumber (E. cichoracearum DC. on Cucumis melo L. and C. sativus L.), and powdery mildew of grape (Uncinula necator [Schw.] Burr. on Vitis vinifera L.) were maintained on plants growing in the greenhouse in Berkeley. Work with clover powdery mildew (E. polygoni on Trifolium pratense L.) was principally conducted at Purdue University, Lafayette, Indiana. The three strains of $E$. polygoni above listed are distinct, morphologically and culturally.

Germination trials were conducted on dry glass slides or on agar. Usually the dry conidia (spores) were shaken from infected greenhouse plants onto slides in the bottom of a garbage can used as a settling chamber. The slides with spores were placed in petri-dish moist chambers at the indicated temperature, and germination was counted after 24 hours. Each value for a given temperature indicates a different trial and is based on a count of 100 or 200 conidia.

Conidia of Erysiphe graminis (figs. 4, 5) were germinated on an agar substrate. The plain agar consisted of 0.6 per cent washed agar and 99.4 per cent water. The nutrient agar consisted of agar and water with 0.6 per cent sucrose, 0.0005 per cent Tween 60 (a polyoxyalkaline derivative of sorbitan monostearate), and 0.00005 per cent lecithin.

For length of germ tubes (fig. 5), each value is the average of 20 germ tubes measured with an eyepiece micrometer; but for length of hyphae per colony (figs. 6 and 10), each value is the average of 5 colonies.

For recording infection of leaves (figs. 8 and 14), a decimal rating scale was used in which 0 indicates no apparent infection and 10 indicates the maximum growth apparent in the series. Each value is the average of 5 leaves.

For determination of the length of hyphae on leaves (figs. 6 and 10), detached leaves on 10 per cent sucrose in the dark were lightly dusted with dry conidia and incubated at the specified time and temperature. The leaves were then cleared in equal parts of alcohol and acetic acid, the fungus stained with acid fuchsin in lactophenol, and the total length of the hyphae per spore was measured microscopically with the aid of an eyepiece micrometer.

For determination of the duration of viability of conidia, the conidia were exposed in several ways. In some trials (fig. 12), the conidia were deposited on dry slides and the slides with spores were placed in jars with $\mathrm{CaCl}_{2}$ (dry) or water (humid) in the bottom of the jars. After various intervals at the indicated temperature, the conidia were used as inoculum on healthy detached cucumber or bean leaves on 8 per cent sucrose solution in petri dishes in the laboratory at about $20^{\circ} \mathrm{C}$. Infection of the assay leaves was noted as 
positive or negative. In other trials (fig. 13), pieces of or entire leaves were exposed in incubators at the test temperature and the prevailing humidity. After various intervals the conidia on the leaves were used as inoculum for detached leaves, and infection was noted as positive or negative.

Conidia of several species of powdery mildews, especially Erysiphe polygoni, are known to germinate better in light than in darkness (Yarwood, 1936); but since light chambers with a series of controlled temperatures were not available, all exposures to test temperatures were in darkness.

\section{DIRECT EFFECT OF TEMPERATURE ON DEVELOPMENT OF POWDERY MILDEWS}

Published records of the direct effect of temperature on powdery-mildew devélopment are summarized in table 1 and figures 1 to 3 . The writers' data are given in figures 1 to 10. Only Erysiphe graminis and E. polygoni have been extensively studied.

Erysiphe graminis. On the basis of 13 independent records (table 1, figs. 1 to 6 ), the average minimum, optimum, and maximum temperatures for Erysiphe graminis are $3^{\circ}, 17^{\circ}$, and $31^{\circ} \mathrm{C}$, respectively. Since several observers have recorded fungus activity at the lowest temperature studied, the given arithmetic average of $3^{\circ}$ is obviously higher than the true minimum. temperature.

Criteria of activity of Erysiphe graminis have been percentage germination in vitro (table 1, figs. 1 to 4 ), length of germ tubes in vitro (table 1 and fig. 5), length of hyphae in vivo (figs. 2 and 6 ), disease development (table 1 ), and rate of maturation of conidia (fig. 2). There is insufficient evidence, however, to indicate which criterion is most useful as an approximation to temperature relations in nature. Percentage germination of conidia on glass (Cherewick, 1944 ; Graf-Marin, 1933 ; Corneli, 1934 ; Pratt, 1943) has been most extensively used. The data of Graf-Marin, Corneli, and Pratt are reasonably consistent with each other. The low minimum and optimum temperatures, and the left-skewed shape of the temperature response curve (figs. 1, 2) as observed by Cherewick might indicate that he worked with a strain of the fungus quite different from that of most other investigators or that there was something unique in his methods. Because the percentage germination after 3 days on agar (fig. 4) was so uniform over such wide portions of the temperature range, it is obviously not a good criterion of temperature response. This method did show, however, that nutrient agar is superior to plain agar, and that spores taken from plants at 11 a.m. germinate better than spores taken at 11 p.m. for most of the temperature range.

The criterion of length of germ tubes in vitro (table 1, fig. 5 ) indicates a higher optimum temperature for Erysiphe graminis than is indicated by percentage germination on glass (table 1) or by length of hyphae on leaves (fig. 6). Temperature-response curves of the length of germ tubes on agar (fig. 5) indicate the optimum temperature more clearly than does percentage germination of the same spores (fig. 4), and the curve of maximum length of germ tubes for each temperature indicates the optimum temperature more clearly than does the curve of average length of germ tubes. 


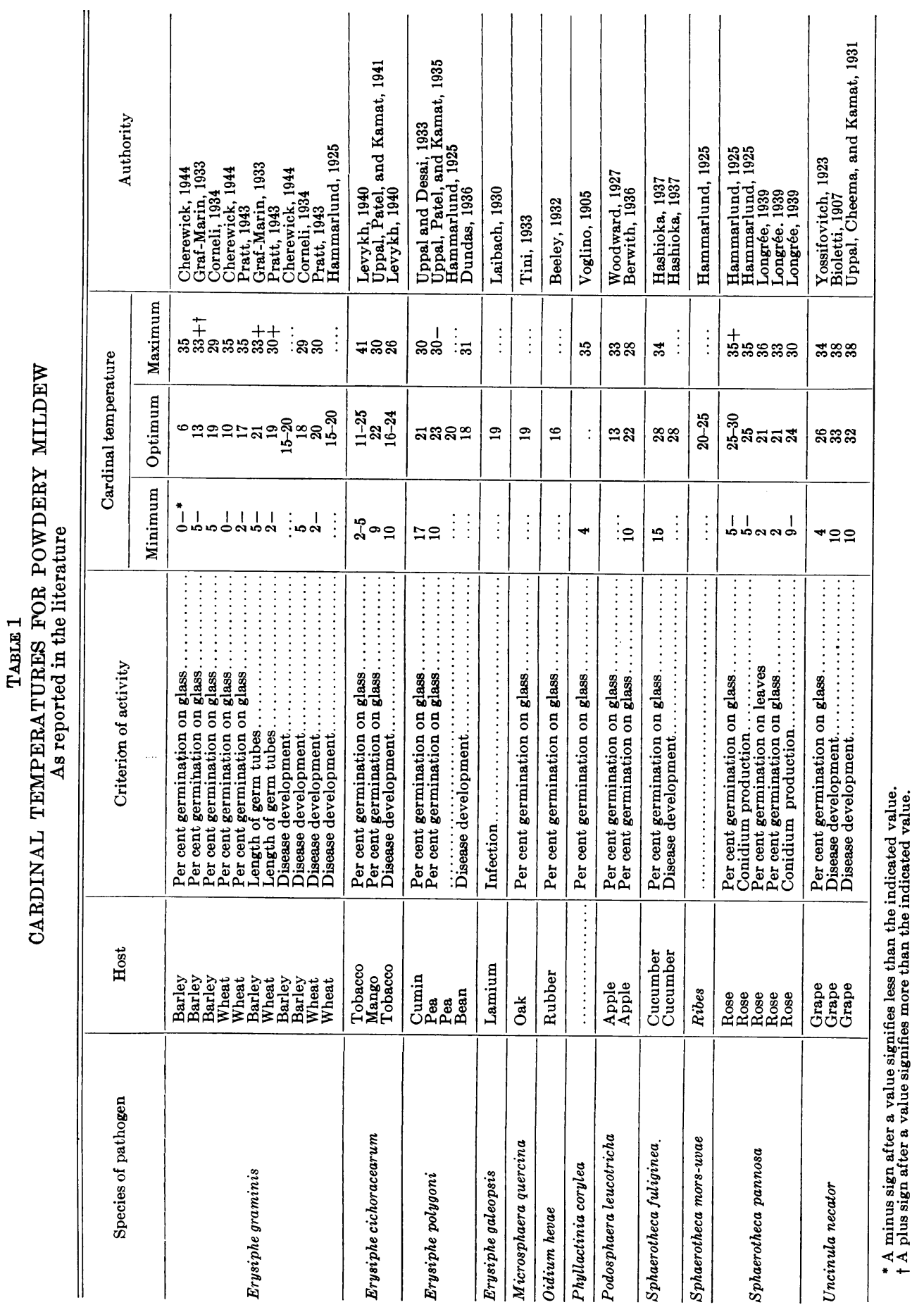




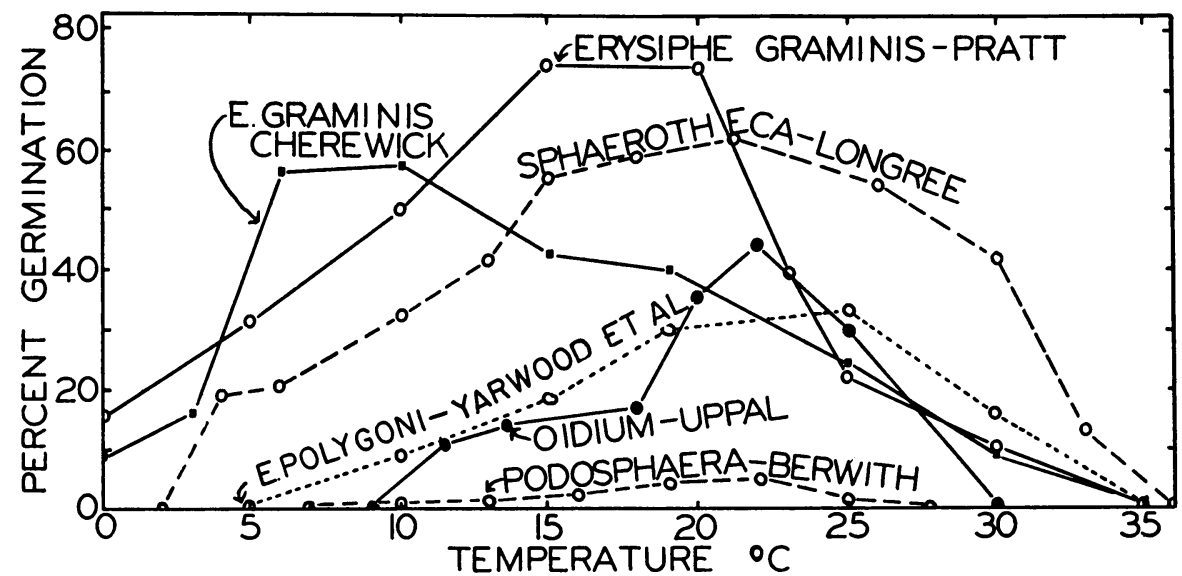

Fig. 1. Effect of temperature on germination of conidia as reported by various authors. The results indicate important differences between fungi and between investigators with respect to absolute amount of germination, the shape of the temperature-response curve, and the values for minimum, optimum, and maximum temperatures. The Oidium of Uppal, Patel, and Kamat (1941) from mango is also referred to as Erysiphe cichoracearum. ("Yarwood, et al." refers to this study.)



Fig. 2. Relation of temperature to certain stated activities of Erysiphe graminis as observed by different investigators. The optimum temperature ranges from about $6^{\circ}$ to $22^{\circ}$ $\mathrm{C}$, but the maximum temperature only from about $30^{\circ}$ to $35^{\circ}$. The data of Cherewick are for $E$. graminis from barley only. 


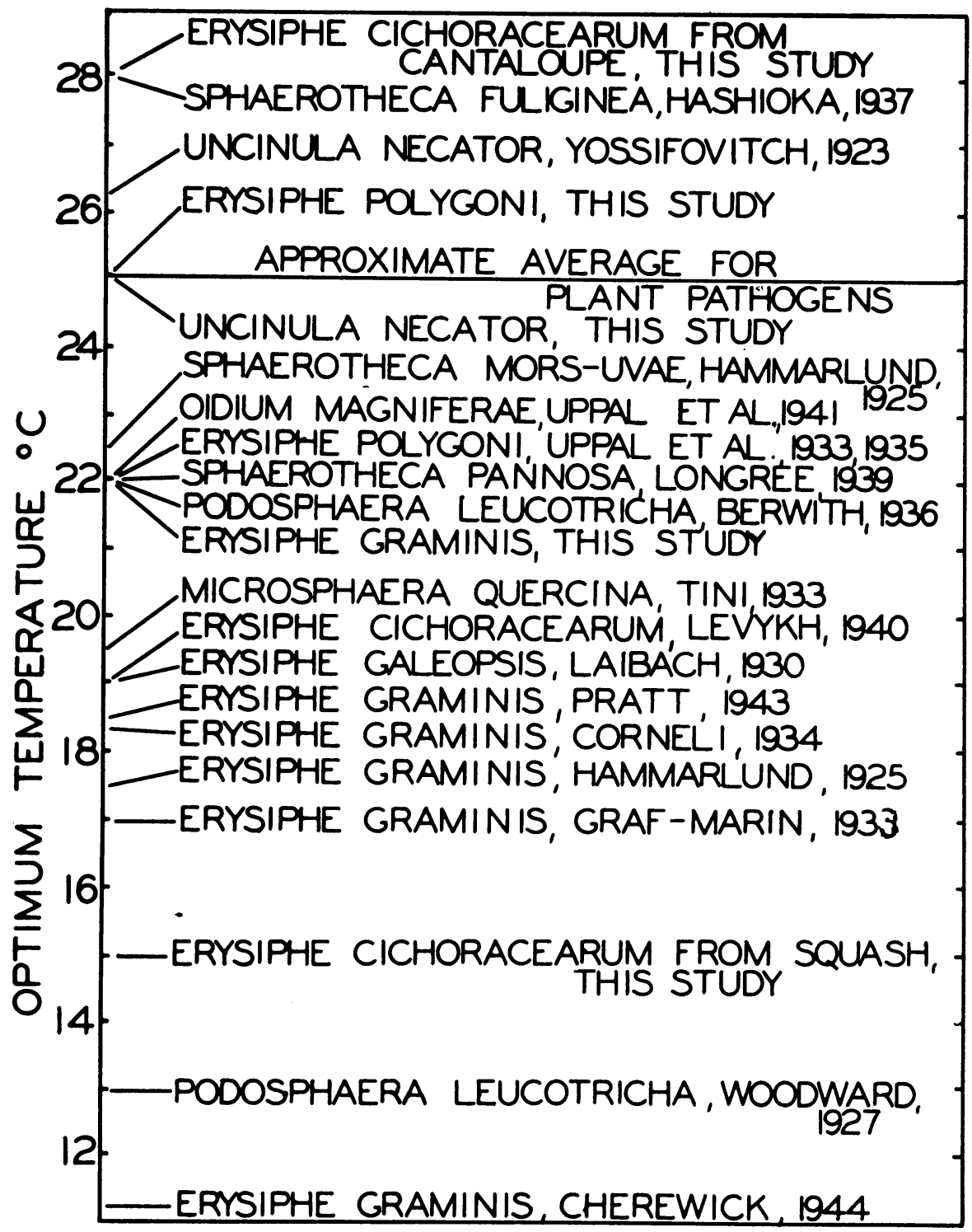

Fig. 3. The optimum temperature of various species of powdery mildews as reported by various investigators. The range in temperature optimum within a species (Erysiphe cichoracearum or $E$. graminis, for example) is about as great as between different species. The average optimum for powdery mildew (about $21^{\circ} \mathrm{C}$ ) is about 4 degrees lower than the average optimum for plant pathogens. 
Length of hyphae on detached leaves (figs. 2 and 6 ) showed greater difference due to temperature than did any other criterion of activity of Erysiphe graminis, and the writers therefore believe it is the best measure of temperature response observed in this study.

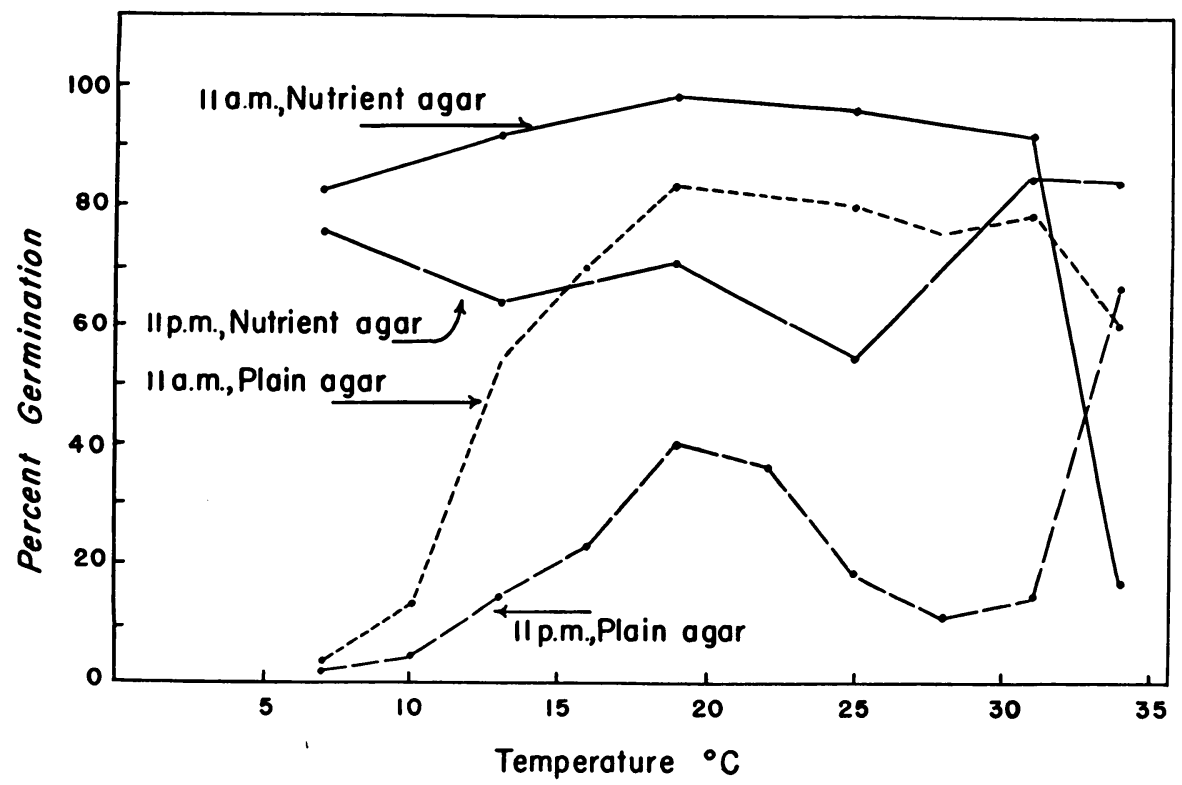

Fig. 4. Effect of temperature, nutrient substrate, and time of day of collecting spores (11 a.m. or 11 p.m.) on the germination in 3 days of Erysiphe graminis conidia from barley. The increased germination due to increasing temperature was clearly apparent only on plain agar, and was more evident with spores collected at 11 a.m. than with ones collected at 11 p.m. Trial of March 11, 1950.

Disease development as a response to temperature (Cherewick, 1944; Corneli, 1934; Pratt, 1943) should be the best criterion of the temperature relations of a disease caused by a powdery mildew or any other pathogen. But suitable facilities for growing infected plants with temperature the only variable are so rare as to almost exclude this method for most investigators.

Erysiphe polygoni. Results of different investigators show more agreement with Erysiphe polygoni than with $E$. graminis. The average minimum, optimum, and maximum temperatures for $E$. polygoni (table 1, figs. 1, 3, 6, 7, and 8 ) are about $8^{\circ}, 23^{\circ}$, and $32^{\circ} \mathrm{C}$, respectively. These cardinal temperatures are believed to be significantly higher than for E. graminis. Figure 7 indicates the range of values for eleven trials of percentage germination of conidia on glass slides. As with $E$. graminis, in the determination of cardinal temperatures, especially the optimum, in vivo growth of hyphae is a more sensitive criterion than percentage germination. In support of this, the temperature coefficient for $E$. polygoni of clover between $15^{\circ}$ and $25^{\circ} \mathrm{C}$ was about 1.9 for percentage germination (fig. 7 ), but about 3.8 for length of hyphae (fig. 6 ) though the coefficient for $E$. polygoni of clover was intermediate among the three strains of this species that were studied (fig. 6). 
Mildew infection on mildew-resistant and mildew-susceptible clovers shows an interesting response to temperature (fig. 8). At $6^{\circ} \mathrm{C}$, the lowest temperature studied, mildew development was about equal on resistant and susceptible plants. At $18^{\circ} \mathrm{C}$, which was about the optimum temperature for these trials, the average mildew infection rating was about twice as great on the

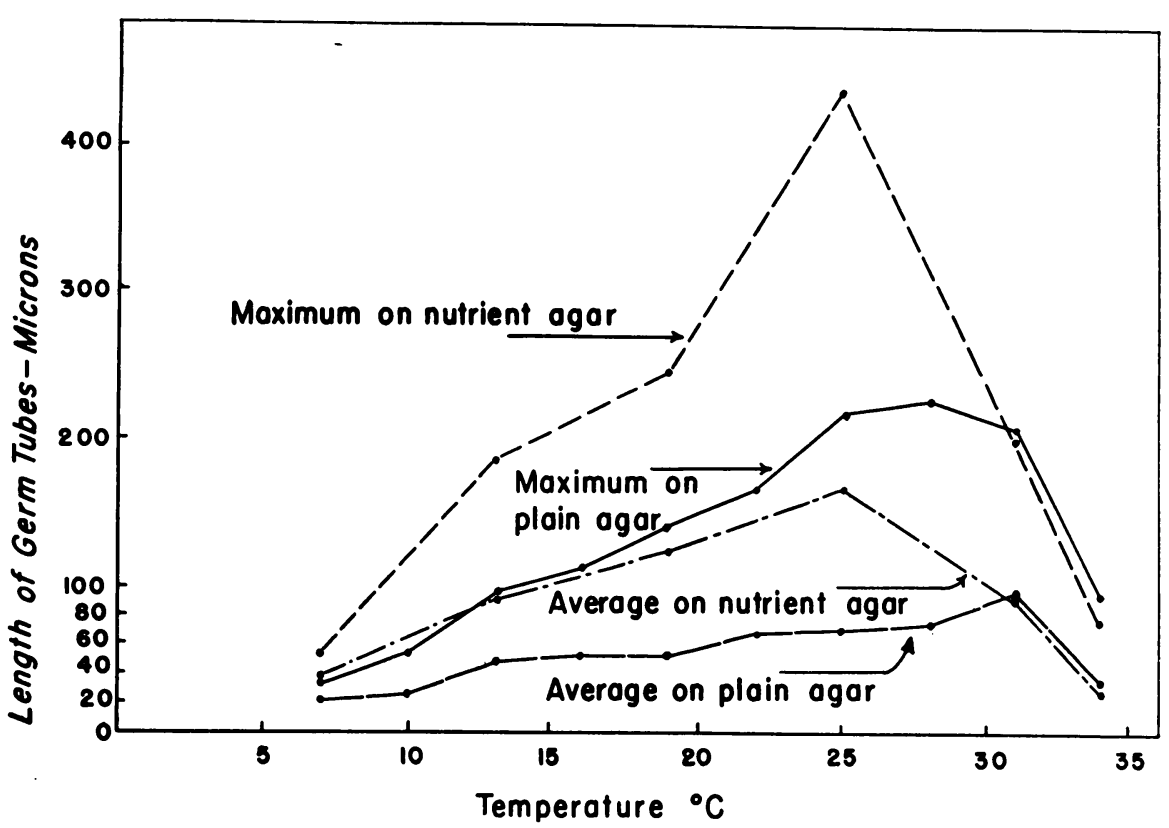

Fig. 5. Effect of temperature and nutrient substrate on the length of germ tubes formed in 3 days by Erysiphe graminis conidia from barley. Part of the same trial as illustrated in figure 4. Length of germ tubes showed a clearer relation to temperature than did percentage germination. The optimum temperature on nutrient agar was about $25^{\circ} \mathrm{C}$, but on plain agar about $28^{\circ}$.

susceptible as on the resistant plants. The maximum temperature was apparently significantly lower for mildew on resistant than on susceptible plants.

Erysiphe cichoracearum. As used here, Erysiphe cichoracearum includes Hashioka's Sphaerotheca fuliginea, which may be the same species. The average minimum, optimum, and maximum temperatures for $\boldsymbol{E}$. cichoracearum are about $9^{\circ}, 22^{\circ}$, and $34^{\circ} \mathrm{C}$ (table 1 , figs. 3,6 ), respectively. $E$. cichoracearum from cantaloupe from the hot Imperial Valley of California showed a temperature optimum of $25^{\circ}$ to $28^{\circ}$ (fig. 6 ) on the basis of in vivo length of hyphae, while a collection of $E$. cichoracearum from squash from the cool Colma district, germinated on glass, showed a temperature optimum of $15^{\circ}$. This difference within a species is about as great as between any two species. $E$. cichoracearum from any source has always germinated poorly on glass in the writers' trials, but Uppal et al. (1941) secured as high as 43 per cent germination.

Sphaerotheca pannosa. The average minimum, optimum, and maximum 


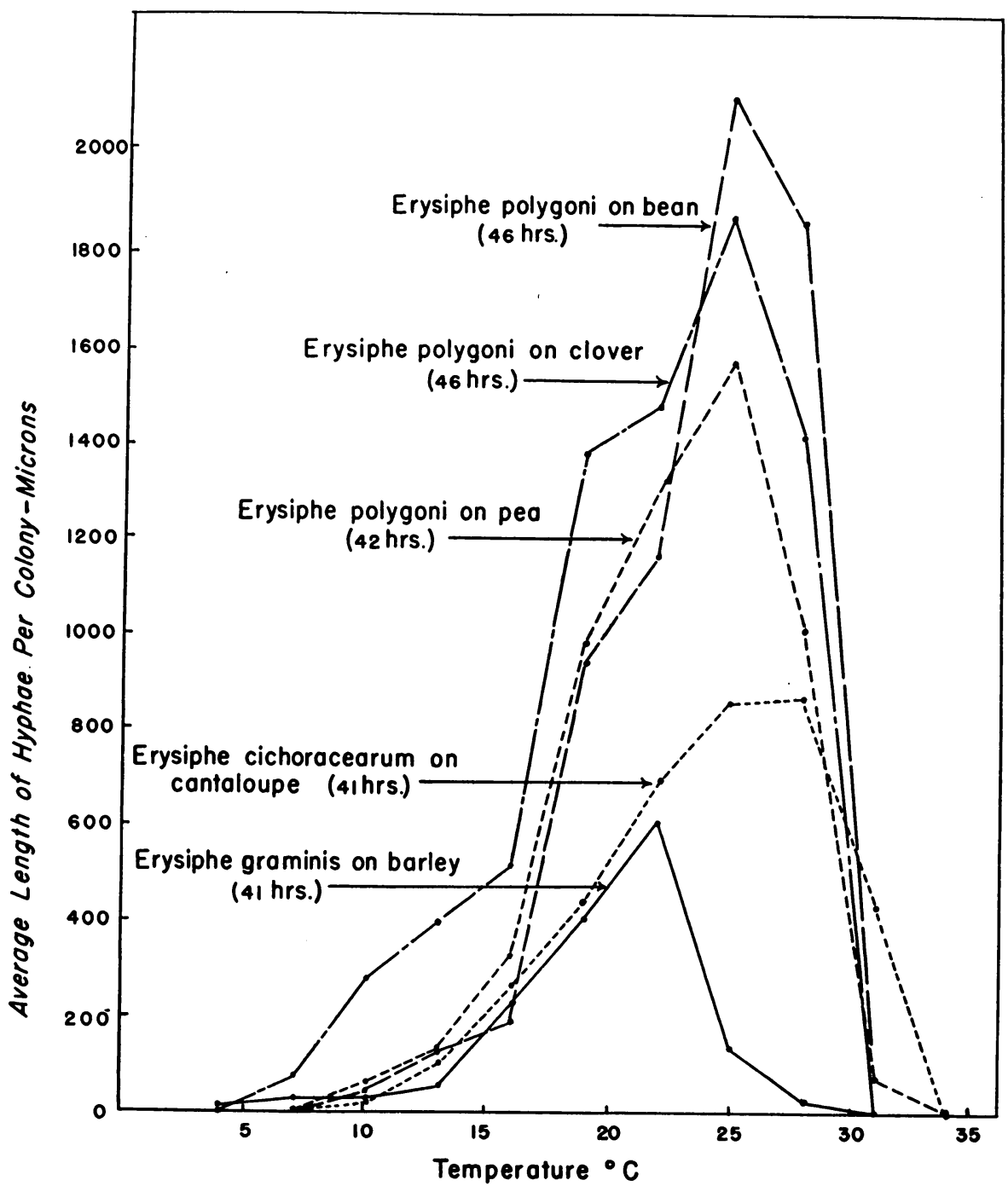

Fig. 6. Effect of temperature on the total length of hyphae per colony of powdery mildews on detached leaves. At their optimum of $25^{\circ} \mathrm{C}$, the three strains of Erysiphe polygoni grew more rapidly than did $E$. cichoracearum at its optimum of $28^{\circ}$ or $E$. graminis at its optimum of $22^{\circ}$.

temperatures for Sphaerotheca pannosa are about $5^{\circ}, 24^{\circ}$, and $34^{\circ} \mathrm{C}$, respectively (table 1, fig. 3). According to Longrée (1939), the temperature range for conidium production is considerably narrower than for germination and growth. According to Hammarlund (1925) (fig. 9), temperature has relatively little effect on number of conidia per conidiophore, but many more conidia are formed in dry air than in humid air at all temperatures.

Uncinula necator. On the basis of the data of Yossifovitch (1923) (table 1) 


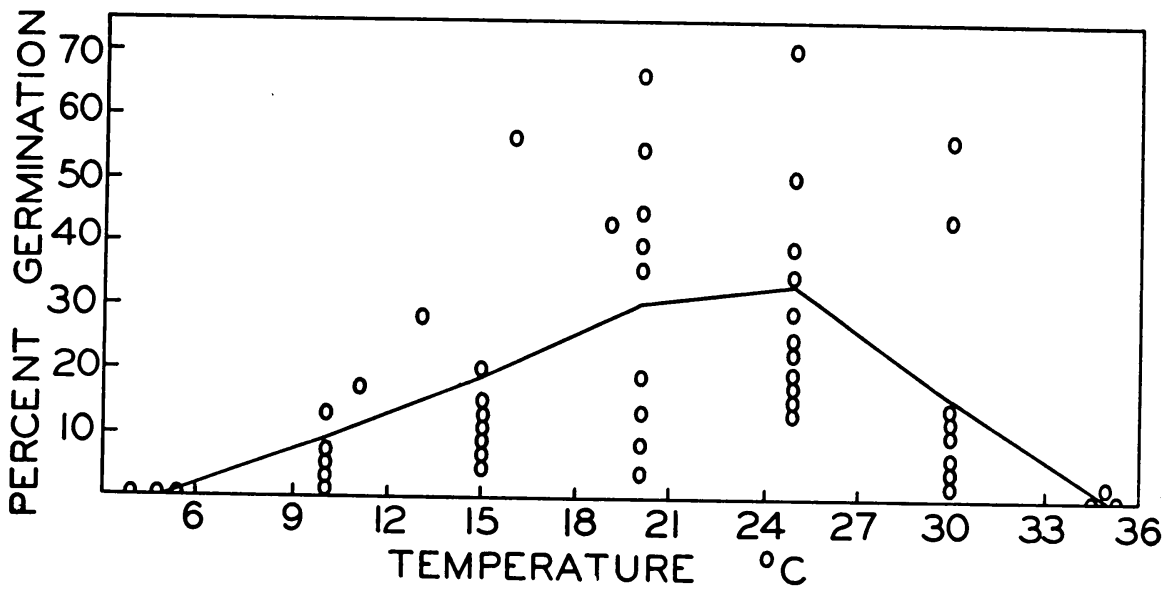

Fig. 7. Effect of temperature on the germination of conidia of Erysiphe polygoni from red clover. The results indicate a minimum of $5^{\circ} \mathrm{C}$, an optimum of $25^{\circ}$, and a maximum of $35^{\circ}$, but show great variation between trials.

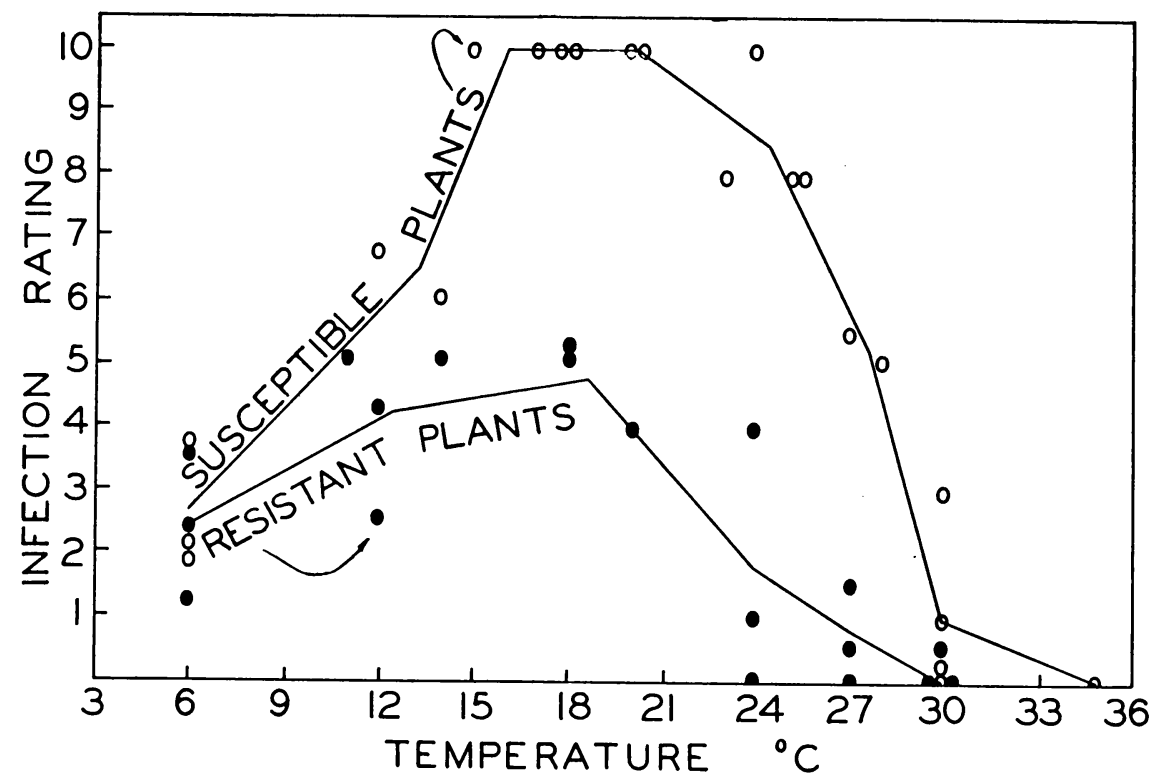

Fig. 8. Effect of temperature on mildew (Erysiphe polygoni) development on susceptible and resistant clover plants. The resistant and susceptible individuals were selected as entire plants under prevailing greenhouse conditions, but the temperature trials were with detached leaves on sucrose solution for 8 days. At low temperatures, mildew growth on resistant plants was similar to that on susceptible plants, but with increasing temperature mildew on the resistant plants became progressively less than on the susceptible plants. At $25^{\circ} \mathrm{C}$ mildew growth on susceptible plants was about seven times that on resistant plants. 
and of this study (fig. 10), the minimum, optimum, and maximum temperatures for Uncinula necator are about $3^{\circ}, 26^{\circ}$, and $36^{\circ} \mathrm{C}$, respectively.

As with Erysiphe cichoracearum, conidia of Uncinula necator germinated poorly on glass and even on leaves. Colonies on the same leaf and in different trials at the same temperature showed much greater variability than did $\boldsymbol{E}$. polygoni, E. cichoracearum, or E. graminis.

Podosphaera leucotricha. The minimum, optimum, and maximum temperatures for Podosphaera leucotricha average about $10^{\circ}, 16^{\circ}$, and $30^{\circ} \mathrm{C}$

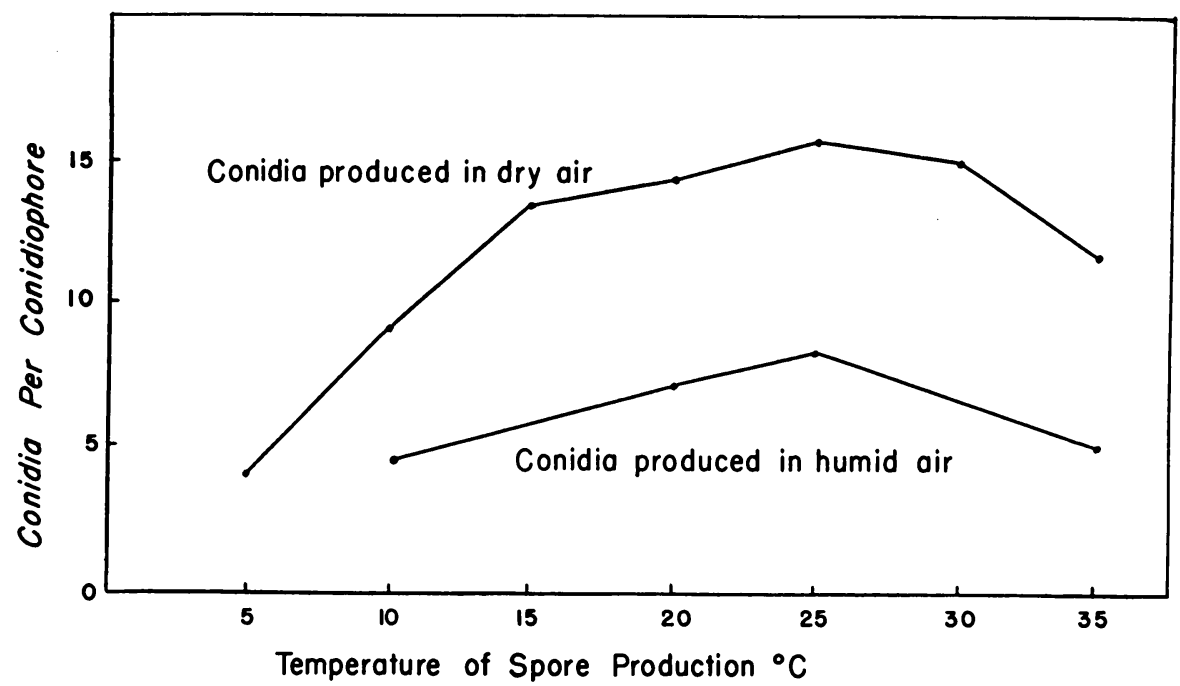

Fig. 9. Relation of temperature to number of conidia of Sphaerotheca pannosa produced in dry air ( $55 \pm 5$ per cent relative humidity) and moist air $(85 \pm 5$ per cent relative humidity). The effect of even this relatively small difference in relative humidity is about as great as the effect of temperature over the range studied. (Data from Hammarlund, $1925)$.

(table 1), but the data are so limited as to make these values uncertain. Conidia of $P$. leucotrich a germinate poorly on glass.

Other Species. With Erysiphe galeopsis, Microsphaera quercina, Phyllactinia corylea, and Sphaerotheca mors-uvae (table 1), only incomplete and unconfirmed data on temperature relations are available.

\section{EFFECT OF TEMPERATURE DURING CONIDIUM PRODUCTION ON GERMINABILITY OF CONIDIA}

Only Hammarlund (1925) seems to have investigated the effect of the environment during conidium production on subsequent germination of the conidia in a constant environment. His data, presented in figure 11, show that the germinability of conidia produced at near the optimum temperature for the organism is much greater than that of conidia produced at near the minimum or maximum temperatures. At any temperature, conidia produced in dry air showed a higher germination than conidia produced in humid air. 
Somewhat related to the above observation is that of Salmon (1900), who observed that chilling of conidia of Sphaerotheca humuli favored their subsequent germination at normal temperatures.

\section{LONGEVITY OF POWDERY MILDEWS AT DIFFERENT TEMPERATURES}

Powdery mildews occur in some of the hottest and coldest agricultural regions; hence, they are presumably able to withstand at some stage in their development the rigors of these climates.

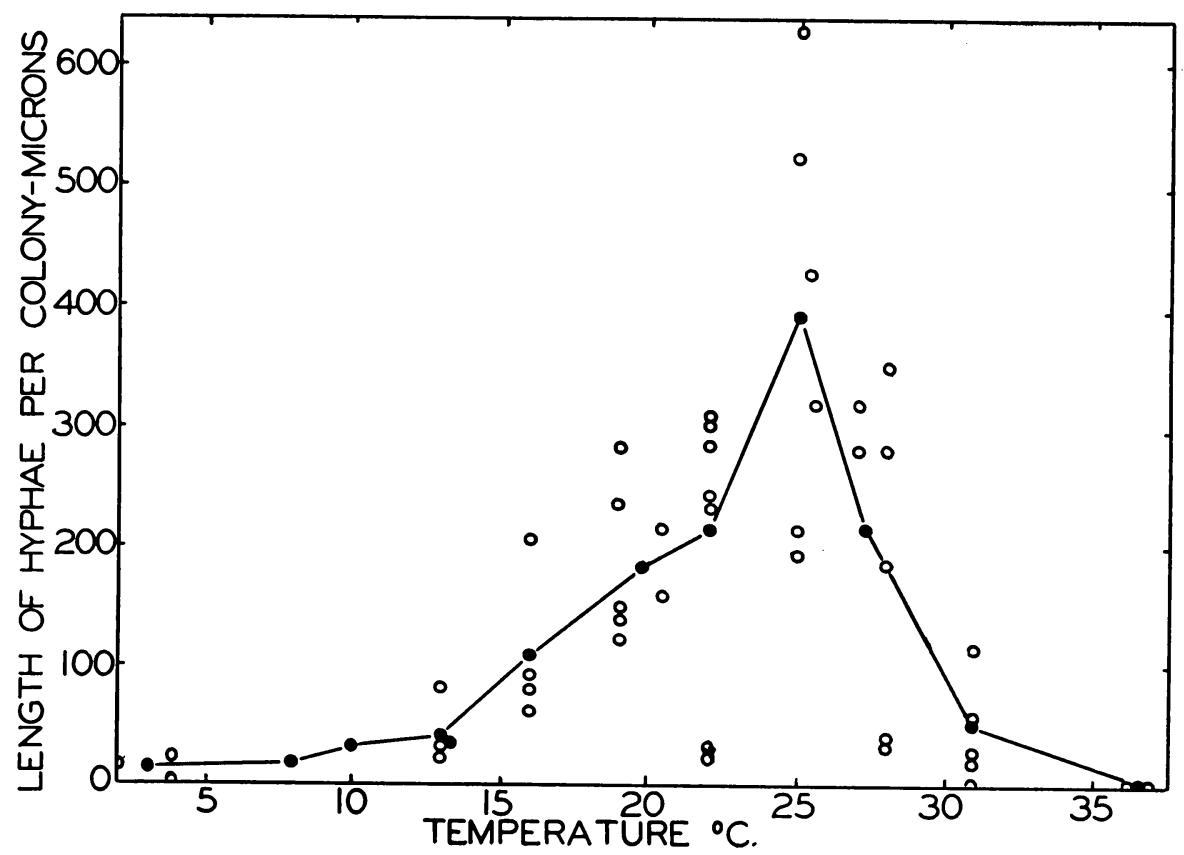

Fig. 10. Average effect (solid circles) of temperature on the length of hyphae per germinated spore of Uncinula necator on detached grape leaves of the variety Clairette blanche 46 hours after inoculation. Each empty circle is the value of a single test.

Since most powdery mildews are believed to pass the dormant season as mycelium in the buds of their hosts, or as perithecia, it is presumably these forms which are most tolerant to temperature extremes. Cherewick (1944) has shown that perithecia of Erysiphe graminis will live at least two years. Perhaps because of difficulties of experimental manipulation, there is little quantitative information on the relation of temperature to these forms. Most studies of temperature tolerance and longevity of powdery mildews have been confined to their conidial stage.

Published data on temperature tolerance of powdery mildews are summarized in table 2, and the data of the writers are given in figures 12 to 15 . For all species, the average maximum longevity of powdery-mildew conidia 
is about 40 days at $-10^{\circ}$ to $0^{\circ} \mathrm{C}, 20$ days at $0^{\circ}$ to $10^{\circ}, 8$ days at $10^{\circ}$ to $20^{\circ}$, 4 days at $20^{\circ}$ to $30^{\circ}$, and 1 day at $30^{\circ}$ to $40^{\circ}$. The greatest longevity recorded is 78 days at $-2^{\circ} \mathrm{C}$ for Erysiphe graminis (Metzger, 1942). Sphaerotheca pannosa is perhaps the shortest-lived of all species studied. $E$. cichoracearum conidia are apparently longer-lived than conidia of $\boldsymbol{E}$. polygoni (figs. 12, 13). This may be because conidia of $E$. polygoni usually either germinate promptly or die at favorable temperatures, while a large percentage of $E$. cichoracearum conidia do not germinate when initially exposed to apparently favor-



Fig. 11. Relation of temperature and humidity of spore production on subsequent germination of conidia of Sphaerotheca pannosa at $18^{\circ}$ C. (Data from Hammarlund, 1925.)

able environmental conditions. $E$. polygoni conidia remained viable longer in a humid than in a dry environment (fig. 12), while the reverse was true with $E$. cichoracearum. Conidia of $E$. polygoni and $E$. cichoracearum exposed in situ lived longer than spores exposed in vitro at all temperatures (fig. 13).

Growing mycelia are apparently more sensitive to high temperature than are quiescent conidia (fig. 14). The LD 50 of $37^{\circ} \mathrm{C}$ air temperature for a 3 -day infection of Erysiphe cichoracearum on cucumber was about 10 hours, while with freshly inoculated leaves it was about 20 hours. For $E$. polygoni the corresponding values were 6 and 13 hours. This also supports the previous finding that $E$. cichoracearum is more tolerant of high temperature than is E. polygoni.

Data on the lethal action on Erysiphe polygoni of short periods in hot water are presented in figure 15. Three-day old infections on bean were killed in about 2 seconds at $55^{\circ} \mathrm{C}, 20$ seconds at $50^{\circ}, 3$ minutes at $45^{\circ}$, and 25 minutes at $40^{\circ}$.

Two types of evidence on the temperature relations of powdery mildews, 




Fig. 12. Effect of storage temperature on the longevity of conidia of Erysiphe cichoracearum from cucumber leaves and $E$. polygoni from bean. Viability decreased with increasing temperature. $E$. cichoracearum was more tolerant of high temperature than was $E$. polygoni. The former lived longer in the dry condition, the latter longer in the humid condition.

TABLE 2

VIABILITY OF POWDERY-MILDEW CONIDIA As reported in the literature

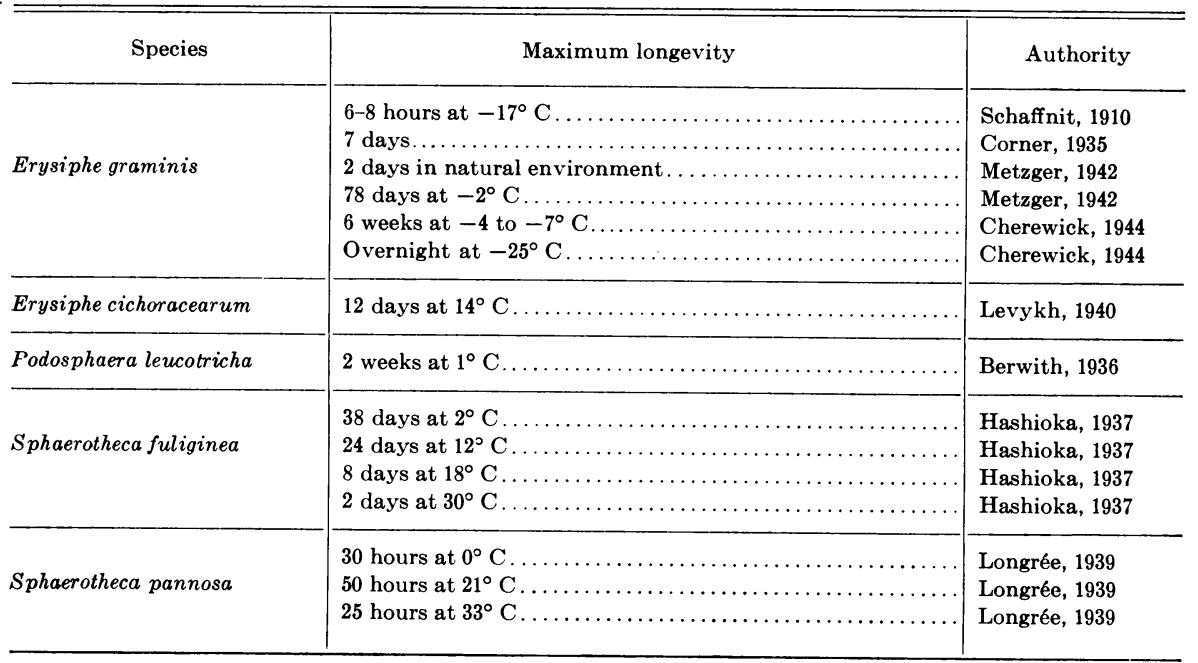




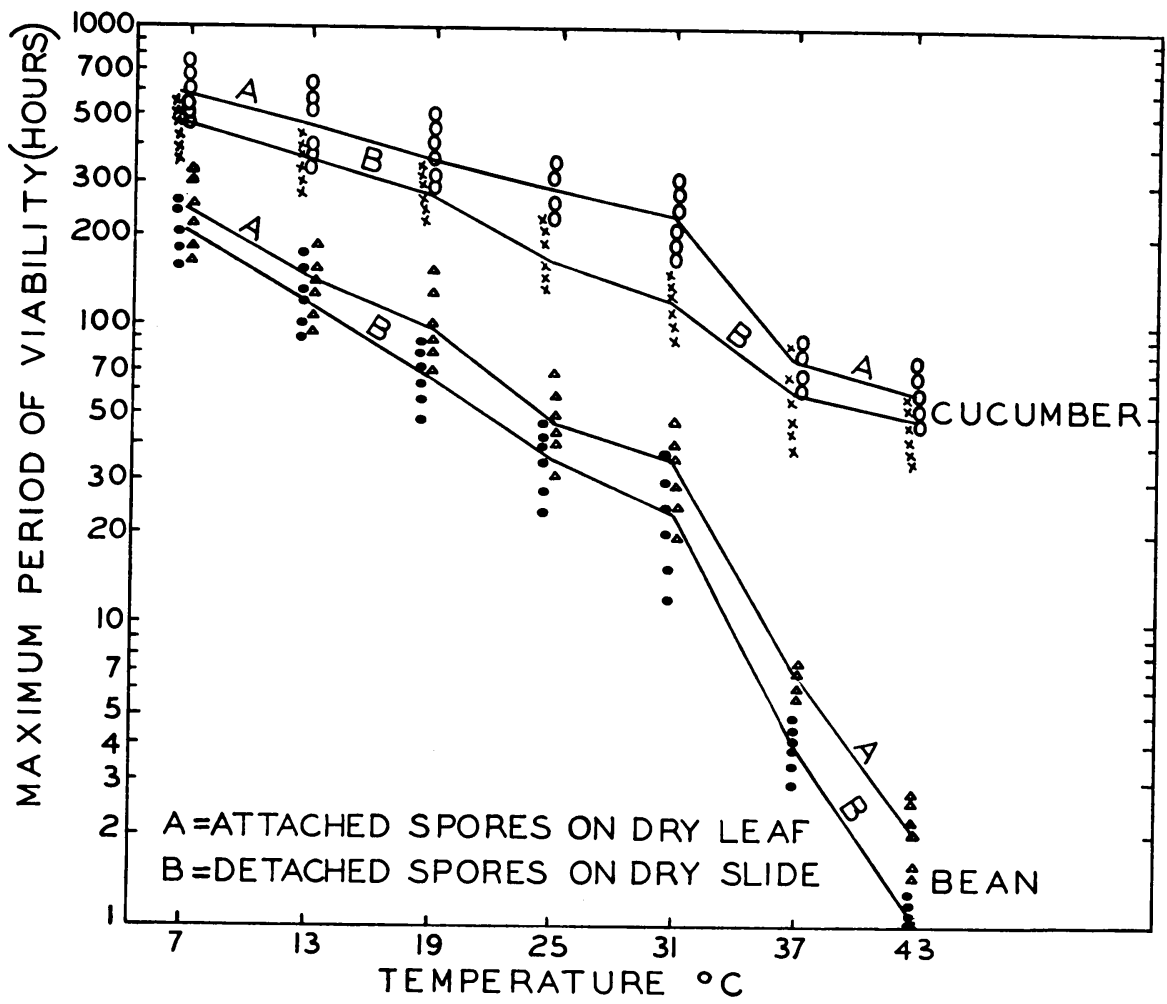

Fig. 13. Effect of temperature and detachment on viability of conidia of Erysiphe cichoracearum from cucumber and of $E$. polygoni from bean. $E$. cichoracearum remained viable longer than $E$. polygoni and for both species the spores in situ remained viable longer than the detached spores.

not supported by adequate quantitative data, are believed worthy of brief review. Since it is well known that air temperatures near the soil surface are the highest to which plants are subjected (Geiger, 1927), the observations that grape powdery mildew is less severe near the soil (Anonymous, 1853, 1855) may be regarded as evidence of its sensitivity to high temperature. The numerous reports and extensive discussion of the control of grape mildew by spraying plants with warm water (Anonymous, 1899) are further evidence of this sensitivity to heat.

The writers believe that temperature responses of fungi can be presented better as straight-line conversions (Cohen and Yarwood, 1952) than by the conventional convex curves skewed toward the maximum temperature. Probably because powdery mildews are obligate parasites, information on their temperature relations cannot be obtained by conventional methods and appears less accurate than that taken for fungi which can be grown on agar substrates. The most satisfactory temperature data of this study may be those on length of hyphae; yet these data give a different shape of temperature-response curve than those based on conventional colony diameter. In 
spite of these difficulties, the straight-line conversion is applied in figure 16 to some of the previous data of this paper.

\section{DISCUSSION}

Powdery mildews (Erysiphaceae) are a rather homogeneous group of fungi clearly distinguished from their closest relatives. Their unique characters are their large, one-celled, thin-walled, hyaline, smooth, vacuolate conidia; the

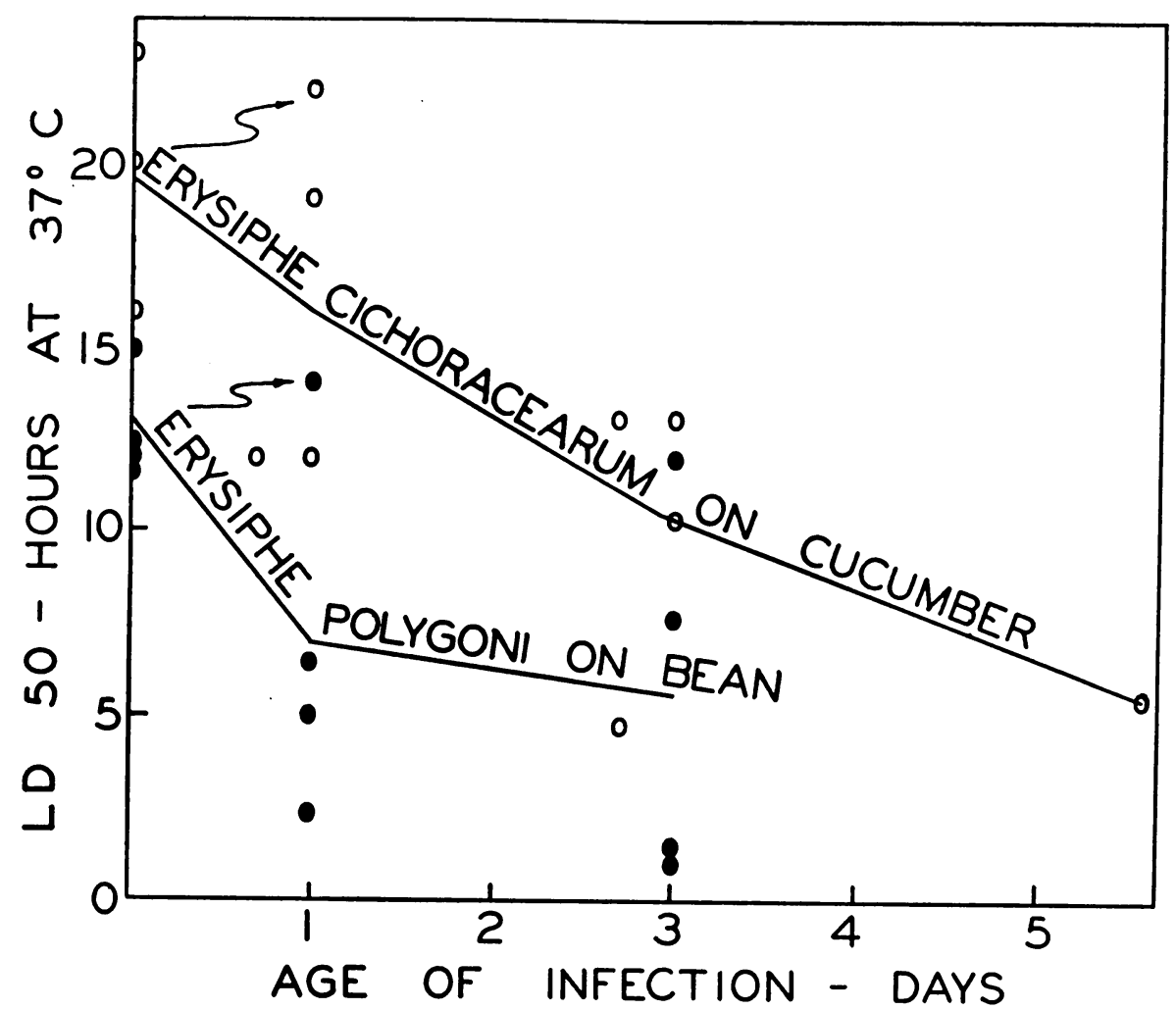

Fig. 14. Relation of age of infection to lethal action of $37^{\circ} \mathrm{C}$ for Erysiphe polygoni on bean and $E$. cichoracearum on cucumber. At different times after inoculation a series of infected leaves was exposed at $37^{\circ}$ air temperature for increasing periods from 1 to 30 hours. With increasing age of infection, the mildew colonies are killed in shorter periods at $37^{\circ} . E$. polygoni is more sensitive to $37^{\circ}$ than is $E$. cichoracearum.

high water content of the conidia ; and superficial hyphae. Although adequate comparative data cannot be cited, evidence in this paper, in comparison with evidence of other investigators for other fungi, indicates that powdery mildew conidia are among the shortest-lived air-disseminated fungus spores. They are comparable in longevity to the sporangia of Peronospora tabacina (Wolf et al., 1934) and the sporidia of Cronartium ribicola (Spaulding and Rathbun-Gravatt, 1926) and are much shorter-lived than the uredospores of 


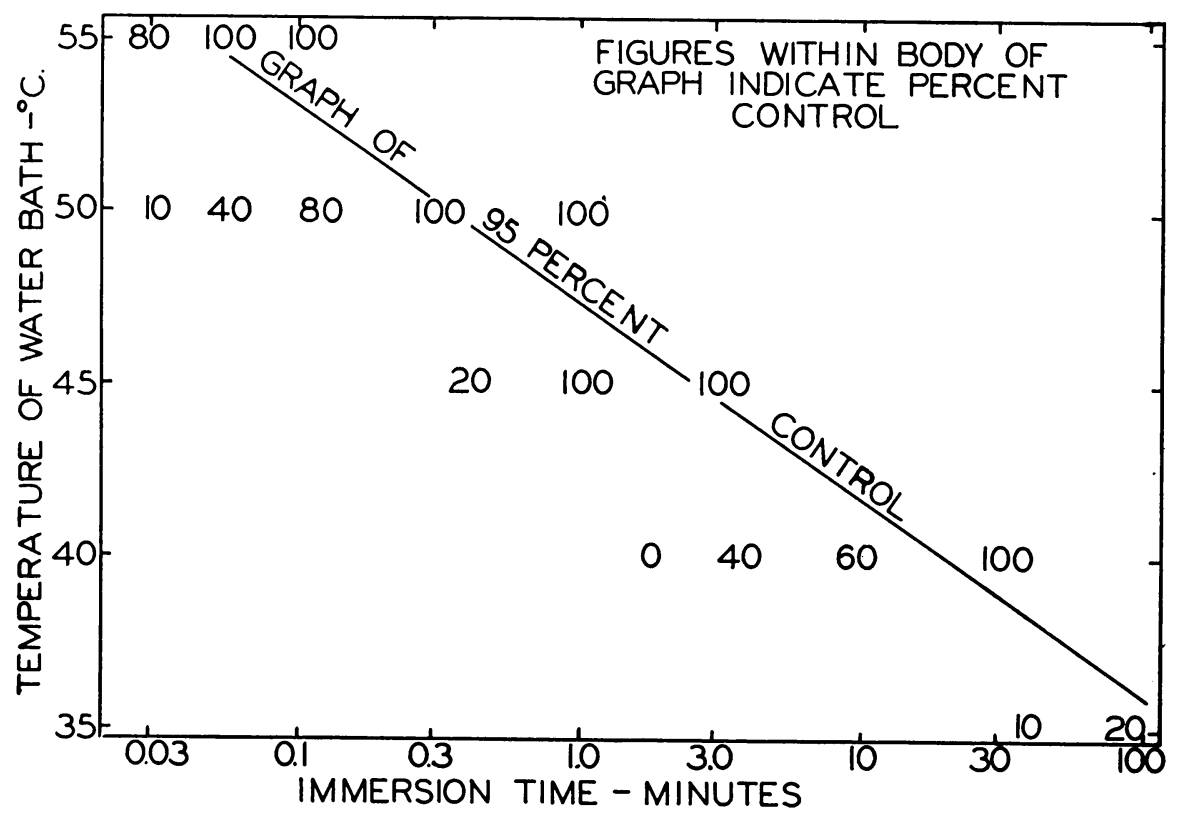

Fig. 15. Lethal action of high temperatures on Erysiphe polygoni on bean. Leaves infected for 3 days were immersed in water at a given temperature for a series of exposure times, then removed, and mildew development was noted at 8 days. The per cent control (eradication by therapy) calculated from the mildew rating is plotted for each immersion temperature. For each 10 degrees rise in temperature the lethal action was increased about 70-fold.

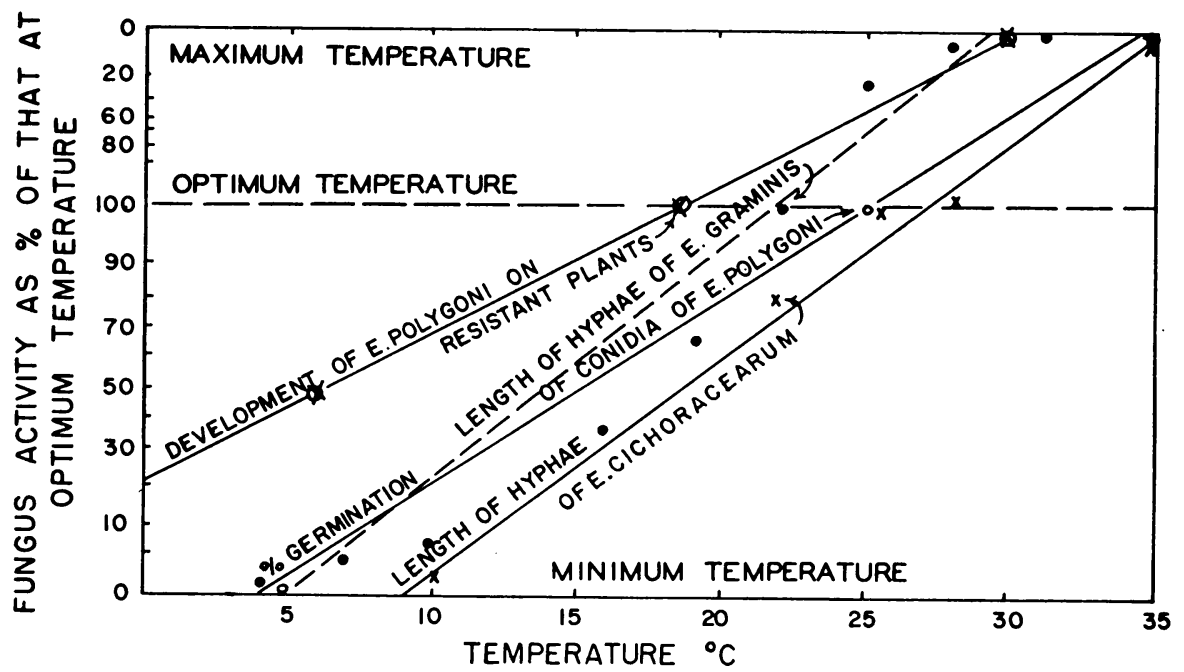

Fig. 16. Temperature relations of certain powdery mildews as a straight-line relation. Data are taken from figures 6,7 , and 8 . The ordinate scale is that described by Cohen and Yarwood (1952). In each case the straight line which appears best to fit the observed data is drawn, but it has not been established that the ordinate conversion used here can correctly be applied to this type of data. 
Puccinia graminis (Peltier, 1922) or the chlamydospores of the smuts (Fischer, 1936). The short life of powdery-mildew conidia is associated with and presumably caused in part at least by their high water content (Yarwood, 1950). In support of this, Erysiphe cichoracearum, with the lowest water content among the powdery mildews studied, has the longest-lived conidia at ordinary temperatures (table 2 , figs. 12,13 ).

Of 856 records of plant-parasitic fungi and bacteria with adequate data given by Togashi (1949), the average optimum temperature for in vitro growth was $26.3^{\circ} \mathrm{C}$. Of 114 important plant pathogens, the average optimum was $24.4^{\circ}$. It therefore appears reasonable to take $25^{\circ}$ as about the optimum for plant pathogens. The average optimum from the records of powdery mildews as given in this study is about $21^{\circ}$. Therefore, while some powdery mildews may have optima above that of the average for plant pathogens, the powdery mildews as a group should be regarded as low-temperature fungi.

On the other hand, Gäumann (1950) indicates that the optimum for fungal and bacterial plant pathogens of the temperate zone is about 15 to $20^{\circ} \mathrm{C}$; but he does not give the basis of this value. If Gäumann's value is accepted, powdery mildews might be regarded as high-temperature fungi.

Within the records presented here there are three apparent correlations between the ecologic distribution of the fungi studied and their optimum temperatures. Erysiphe cichoracearum from cantaloupe (figs. 3,6), with an optimum temperature of about $28^{\circ} \mathrm{C}$, was taken from the Imperial Valley, which is one of California's hottest agricultural regions. E. cichoracearum from squash, with an optimum of $15^{\circ} \mathrm{C}$, was taken from Colma, one of California's coolest agricultural regions. Of the records of $E$. graminis, that by Cherewick (1944), who probably worked at the highest latitude reported in this study, indicates the lowest optimum for this fungus. Also E. graminis, with the lowest average optimum temperature of any species, is principally a pathogen of the winter (especially in California) and spring months; whereas the other powdery mildews listed are principally summer pathogens. 


\section{LITERATURE CITED}

\section{ANONYMOUS}

1853, 1855. [Grape mildew.] Gard. Chron. [London] $13: 740 ; 15: 532,693-94$.

1899. [Control of grape powdery mildew with hot water.] Gard. Chron. ser. 3, 25:334-35, $383-84$; 26 :14, 33, 48, 74, 94, 113, 134.

1950. Powdery mildew of cucumbers, pumpkins, and related plants. Agr. Gaz. N. S. W. 61:587-88.

BeELEY, F.

1932. Effect of meteorological factors on the virulence of Oidium Heveae in Malaya. Rubber Res. Inst. Malaya Jour. 4:104-14.

BER.WITH, C. E.

1936. Apple powdery mildew. Phytopathology 26:1071-73.

BIOLETTT, F. T.

1907. Oidium or powdery mildew of the vine. California Agr. Exp. Sta. Bul. 186:315-50. CHEREWICK, W. J.

1944. Studies on the biology of Erysiphe graminis DC. Canad. Jour. Res. sec. C (Canad. Jour. Bot.) 22:52-86.

CoHeN, Morris, and C. E. YARWOOD

1952. Temperature relations of fungi as a straight line transformation. Plant Physiol. $27(3): 634-38$.

CoRNELI, E.

1934. Temperature di germinazione di spore fungini in relazione alli infezioni sugli ospiti. (Temperatures of germination of fungal spores in relation to infection of the hosts.) Nuovo Giorn. Bot. Ital. (n.s.) 41:121-33. Abstract in: Rev. Appl. Mycol. 13:719. 1934.

CORNER, E. J. H.

1935. Observations on resistance to powdery mildews. New Phytol. 34:180-200.

Dundas, B.

1936. Inheritance of resistance to powdery mildew in beans. Hilgardia $10: 243-53$.

Fischer, GEORGE W.

1936. The longevity of smut spores in herbarium specimens. Phytopathology $26: 1118-27$.

GäUMANN, E.

1950. Principles of plant infection. English translation by W. B. Brierley. 543 p. Crosby Lockwood, London, England.

GEIGER, RUDOLF

1927. Das Klima der bodennahen Luftschicht. Die Wissenschaft 78:1-246.

Graf-Marin, Alberto

1933. Studies on powdery mildew of cereals. New York (Cornell) Agr. Exp. Sta. Mem. $157: 1-48$.

HAMMARLUND, C.

1925. Zur Genetik, Biologie und Physiologie einiger Erysiphaceen. Hereditas 6:1-126.

HASHIOKA, Y.

1937. Relation of temperature and humidity to Sphaerotheca fuliginea (Schlecht.) Poll. with special reference to germination, viability, and infection. Nat. Hist. Soc. Formosa Trans. 27:129-45.

LAIBACH, F.

1930. UUber die Bedingungen der Perithezienbildung bei den Erysipheen. Jahr. f. Wiss. Bot. 72:106-36.

LEVYKH, P. M.

1940. [The influence of temperature and air humidity on the infection of tobacco by powdery mildew, Oidium tabaci Thuem.] A. I. Mikoyan Pan-Soviet Sci. Res. Inst. Tob. and Indian Tob. Ind. (VITIM) Rostoff-on-Don, Publ. 141:97-111. Abstract in: Rev. Appl. Mycol. $20: 90.1941$.

LONGREE, KARLA

1939. The effect of temperature and relative humidity on the powdery mildew of roses. New York (Cornell) Agr. Exp. Sta. Mem. 223:1-43. 
METZGER, ILSE

1942. Versuche zur Aufbewahrung lebender Sporen von Weizen- und Gerstenmehltau. Kühn Arch. $56: 163-72$.

Peltier, George L.

1922. A study of the environmental conditions influencing the development of stem rust in the absence of the alternate host. I. The viability of the urediniospores of Puc-

PratT, R. cinia graminis tritici Form III. Nebraska Agr. Exp. Sta. Res. Bul. 22:1-15.

1943. Influence of temperature on the infection of wheat by the powdery mildew, Erysiphe graminis tritici. Torrey Bot. Club Bul. 70:378-85.

SALMON, ERNEST S.

1900. The strawberry mildew (Sphaerotheca Humuli (DC.) Burr). Roy. Hort. Soc. Jour. $25: 132-38$.

SchaffNit, E.

1910. Studien über den Einfluss niederer Temperaturen auf die pflanzliche Zelle. KaiserWilhelm-Inst. f. Landw. Mitt. 3:95-115.

Spaulding, Perley, and Annie Rathbun-GravatT

1926. The influence of physical factors on the viability of sporidia of Cronartium ribicola Fischer. Jour. Agr. Res. 33:397-433.

TAYLOR, W. H.

1923. Vine culture under glass. Diseases and pests of the vine. New Zeal. Jour. Agr. 26 : $172-77$.

Tini, G.

1933. Prove di germinazione di spore di Oidium quercinum. (Germination tests of the spores of Oidium quercinum.) Riv. Pat. Veg. 23:43-45. Abstract in: Rev. Appl. Mycol. 12:542. 1933.

TOGASHI, K.

1949. Biological characters of plant pathogens. Temperature relations. 478 p. Meibundo, Tokyo.

Uppal, B. N., G. S. Cheema, and M. N. Kamat

1931. Powdery mildew of grape and its control in Bombay. Bombay Dept. Agr. Bul. 163:1-30.

UpPaL, B. N., and M. K. DesaI

1933. Cumin powdery mildew in Bombay. Bombay Dept. Agr. Bul. 169:1-16.

Uppal, B. N., M. K. Patel, and M. N. Kamat

1935. Pea powdery mildew in Bombay. Bombay Dept. Agr. Bul. 177:1-12.

1941. Powdery mildew of the mango. Bombay Univ. Jour. 9(5):12-16.

VoGLino, P.

1905. Contribuzione allo studio della Phyllactinia corylea (Pers.) Karst. Nuovo Giorn. Bot. Ital. 12:313-27.

Wolf, F. A., L. F. Dixon, Ruth McLean, and F. R. Darkis

1934. Downy mildew of tobacco. Phytopathology $24: 337-63$.

WOODWARD, R. C.

1927. Studies on Podosphaera leucotricha (Ell. and Ev.) Salm. I. The mode of perennation. Brit. Mycol. Soc. Trans. 12:173-204.

YARWOOD, C. E.

1936. The diurnal cycle of the powdery mildew Erysiphe polygoni. Jour. Agr. Res. 52: 645-57.

1946. Detached leaf culture. Bot. Rev. 12:1-56.

1950. Water content of fungus spores. Amer. Jour. Bot. $37: 636-39$.

YossiFovitch, MLADEN

1923. Contribution à l'étude de l'Ö̈dium de la vigne et de son traitement. Thèse Doct. Univ. Toulouse, France. Abstract in: Soc. Bot. de France Bul. 70:574. 1923. 
The journal Hilgardia is published at irregular intervals, in volumes of about 600 pages. The number of issues per volume varies.

Subscriptions are not sold. The periodical is sent as published only to libraries, or to institutions in foreign countries having publications to offer in exchange.

You may obtain a single copy of any issue free, as long as the supply lasts; please request by volume and issue number from:

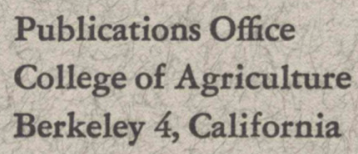

The limit to nonresidents of California is 10 separate issues on a single order. A list of the issues still available will be sent on request.

In order that the information in our publications may be more intelligible it is sometimes necessary to use trade names of products or equipment rather than complicated descriptive or chemical identifications. In so doing it is unavoidable in some cases that similar products which are on the market under other trade names may not be cited. No endorsement of named products is intended nor is criticism implied of similar products which are not mentioned. 